\title{
MINERALOGY AND PHYSICAL UPGRADING OF FERGUSONITE-Y AND HF-ZIRCON IN THE MINERALIZED PEGMATITE OF ABU DOB GRANITE, CENTRAL EASTERN DESERT, EGYPT.
}

\author{
Raslan, M. F. ${ }^{*}$ and Fawzy, M. M. ${ }^{\prime}$ \\ *E-mail address: raslangains@hotmail.com \\ ${ }^{\dagger}$ Corresponding E-mail address: mm1_fawzy@yahoo.com \\ ${ }^{*}, \dagger$ Physical Dressing Department, Nuclear Materials Authority, Cairo, Egypt.
}

\begin{abstract}
Fergusonite-Y occurs at the mineralized pegmatite injected in Abu Dob granitic pluton, Central Eastern Desert of Egypt as dark brown, anhedral clusters of distinguishable megascopic crystals up to tens of millimeters. The mineral is intimately intergrown with Hf-Zircon. Heavy minerals mineralogy for the studied samples revealed that both fergusonite-Y and Hf-Zircon could reach $28 \%$ by weight of the original rock sample. Beside these minerals, some kasolite, titanite and allanite-Ce minerals occur in much lower amount. Allanite-Ce was found as numerous inclusions of variable size and pattern in titanite. Detailed microscopic examination, X-ray diffraction (XRD) and Environmental Scanning Electron Microscope (ESEM) were used to identify and describe the studied minerals.

Physical upgrading of these minerals was carried out using gravitative and magnetic separation techniques. Gravitative separation proved rather good potentialities to attain a good concentrate of both fergusonite-Y and Hf-Zircon with an acceptable recovery. By applying the laboratory Carpco high intensity lift-type magnetic separator for the tabling concentrates, it was possible to attain a good separation between fergusonite- $Y$ as magnetic concentrate and Hf-Zircon as non-magnetic concentrate. Due to the economic importance of the studied minerals and their metal values as they are used in several industrial applications, it is recommended to subject both of the final concentrates to proper hydrometallurgical treatment to extract their metal content.
\end{abstract}

Keywords: Mineralized pegmatite, fergusonite-Y, Hf-zircon, physical upgrading.

\section{INTRODUCTION}

Several studies worldwide have revealed the presence of granite-pegmatite-hosted raremetal mineralizations including $\mathrm{Nb}-\mathrm{Ta}$ oxides and zircon [1-8]. Rare-metal mineralization is particularly and genetically associated with post - orogenic, geochemically distinctive granitoids $[9,10]$.

According to Cerny's [11] pegmatite classification, the rare-earth element (REE) subclass is characterized by the niobium-yttrium-fluorine (NYF) and zirconiumniobium-fluorine (ZNF) family signatures. NYF pegmatites are distinguished by the signature $\mathrm{Y}, \mathrm{Nb}>\mathrm{Ta}$, HREE, $\mathrm{U}, \mathrm{Th}$, and $\mathrm{F}$, whereas $\mathrm{ZNF}$ pegmatites are distinguished by the signature $\mathrm{Zr}, \mathrm{Nb}>>\mathrm{Ta}, \mathrm{Y}, \mathrm{Th}, \mathrm{P}$, and $\mathrm{F}$. From the viewpoint of exploration, postorogenic, A2- type granites are the most favorable sites for the localization of rare-metal pegmatitic mineralization of NYF affinity. These granites are characterized by 
mineralogical and geochemical signatures, i.e., they are transolvus, alkaline, and metaluminous to mildyperaluminous with annite-siderophyllite mica as a sole mafic mineral [12].

Fergusonite, a yttrium niobate $\left(\mathrm{YNbO}_{4}\right)$ is a complex oxide that contains various rare earth elements with yttrium and niobium as dominant components. Yttrium is a vital component in phosphor-based fluorescent lighting, Smartphone screens and batteries while niobium alloys are used to manufacture superconducting magnets for medical hardware such as magnetic resonance imaging (MRI) and nuclear magnetic resonance (NMR) instruments. A new use of niobium is in a solid niobic acid that catalyzes the conversion of palm oil to bio-diesel fuel [13].

Gabal Abu Dob represents a part of Kadabora younger granites batholiths located in the Central Eastern Desert of Egypt. Kadabora batholith lies at the intersection of latitudes $25^{\circ} 30^{\prime} \mathrm{N}$ and longitude $34^{\circ} 30^{\prime} \mathrm{E}$ (figure 1). These younger granites contain numerous pegmatite bodies that are associated with radioactive anomalies. Pegmatites, of G. Abu Dob, are usually of the zoned type. The zonation starts with alkali feldspar at the core followed the quartz at the margin (figure 2). The alkali feldspar varies in color from rose to whitish. Fergusonite occurs at the mineralized pegmatite injected in Abu Dob granitic pluton, as dark brown, anhedral clusters of distinguishable megascopic crystals up to tens of millimeters. The mineral is intimately intergrown with Hf-Zircon (figure 3). Many author studied Kadabora area such as Hume [14], Ibrahim et al. [15], Ibrahim [16], Dawood [17], Attawiya et al [18] and Ammar [19].

Accordingly, the aim of the present paper is to identify the mineralogical and chemical characteristics of the radioactive as well as the economic heavy minerals of Abu Dob pegmatites in Kadabora area and investigate the potentialities of physically upgrading of the studied minerals.

\section{SAMPling AND ANAlytical TeChNiQUeS}

The original rock sample of the studied radioactive Abu Dob pegmatite was subjected to controlled size reduction to $-3 \mathrm{~mm}$ using a combination of jaw crushers and rod mill crusher. This was followed by screening at $1.00 \mathrm{~mm}$ screen size. The undersize $(-1.0$ $\mathrm{mm}$ ) was deslimed using a desliming cone. The deslimed fraction was dried and fractionated using a set of screens starting from $1.00 \mathrm{~mm}$ down to $0.063 \mathrm{~mm}$ which represent the best size for good liberation and also suitable for physical processing.

The liberated size fractions were subjected to heavy-mineral separation using bromoform (specific gravity $=2.85 \mathrm{gm} / \mathrm{cm} 3$ ). From the obtained heavy fractions, pure mineral grains were manually picked and investigated under a binocular microscope. Some of the picked mineral grains were subjected to X-ray diffraction analysis using a Phillips X-ray diffractometer (Model PW-105018) and an environmental scanning electron microscope (ESEM). This instrument includes a Philips XL 30 energydispersive spectrometer (EDS) unit. The applied analytical conditions were an accelerating voltage of $30 \mathrm{kV}$ with a beam diameter of $1-2 \mu \mathrm{m}$ for a counting time of $60-120 \mathrm{~s}$ and a minimum detectable weight concentration ranging from $0.1 \mathrm{wt}$. $\%$ to 1 wt. \%. The magnetic behavior of the studied minerals was investigated individually using a Frantz Isodynamic Separator (Model LB 1). Physical separation was carried out 
using laboratory Wilfely shaking table 13 and the laboratory Carpco high intensity lifttype magnetic separator Model MLH (13) III-5.All these analyses were carried out at the laboratories of the Egyptian Nuclear Materials Authority (NMA).

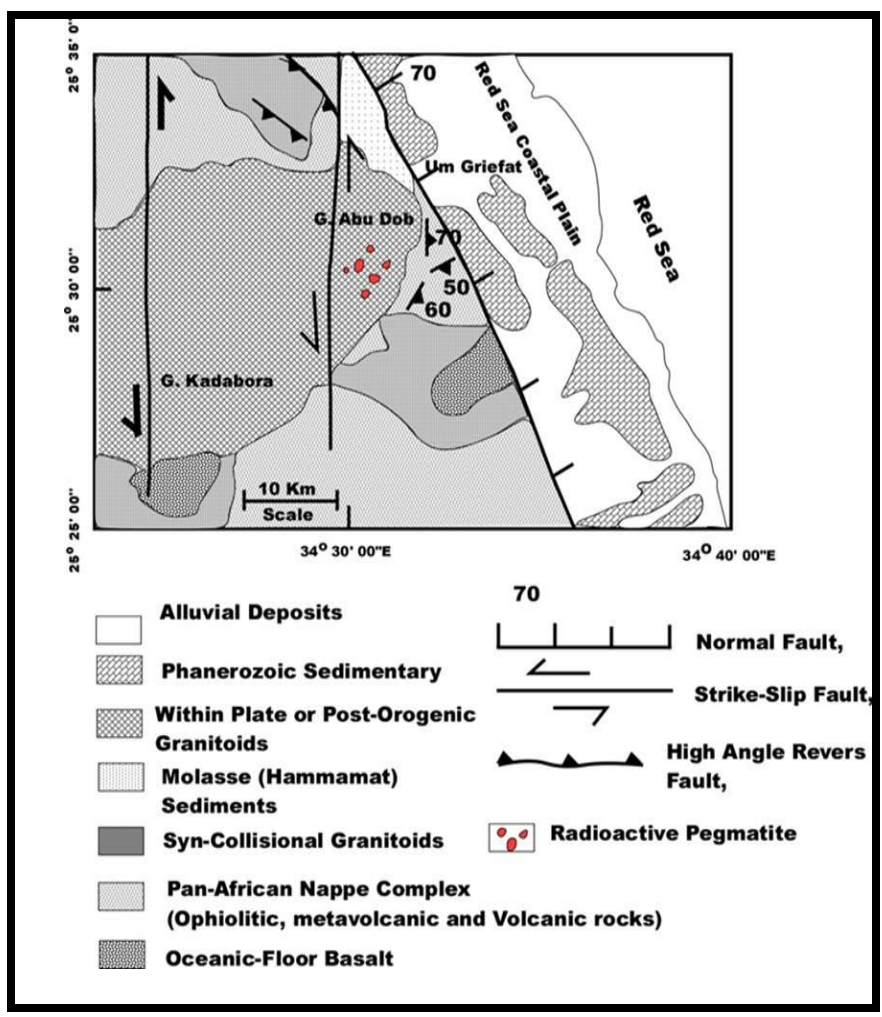

Fig. 1: Geologic map of Abu Dob area (after Abdeen et. al. [20]).

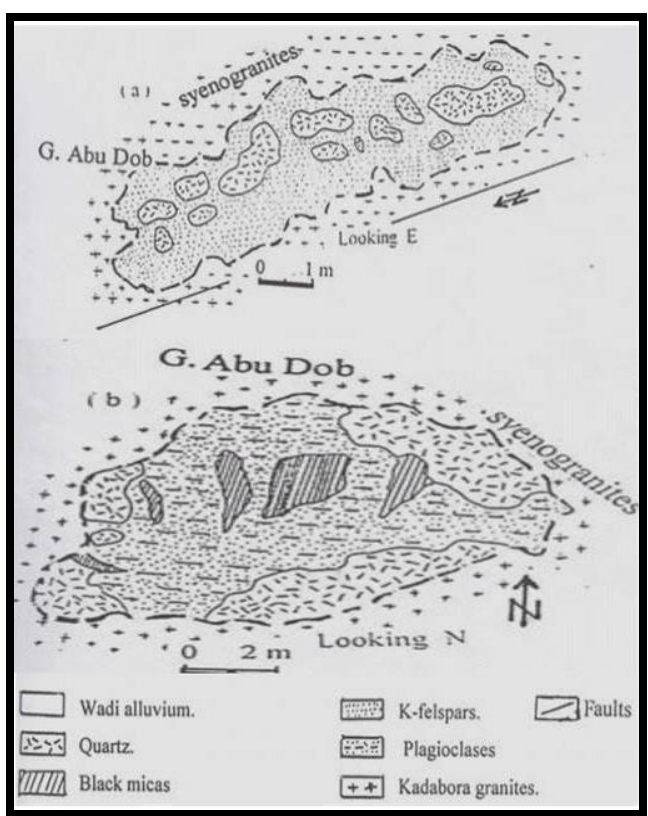

Fig. 2: Sketch for the studied zoned pegmatitic bodies in G. Abu Dob. 


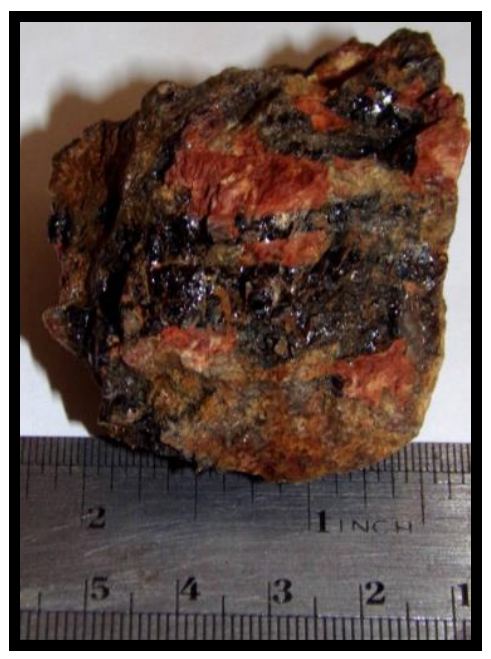

Fig. 3: Close-up photographs showing megacrystals of fergusonite and zircon associated to Abu Dob pegmatite present as large black and brown grains.

\section{RESULTS AND DISCUSSION}

\subsection{Mineralogical Investigation}

\subsubsection{Fergusonite-Y: [(Y, REE $\left.>\mathrm{Ca}, \mathrm{U}, \mathrm{Th})(\mathrm{Nb}, \mathrm{Ta}) \mathrm{O}_{4}\right]$}

Under the binocular microscope, the defined fergusonite grains separated from Abu Dob pegmatite are generally massive grains of anhedral to subhedral and granular form and having a characteristic vitreous or resinous luster. In addition, the investigated mineral crystals are generally translucent, compact, metamict and hard. The fergusonite crystals are mainly yellowish brown (figure 4A) velvet-yellow brown to honey yellow in color (figure 4D) and very deep brown (figure 4G). Environmental Scanning Electron Microscope (ESEM) data of the studied fergusonite crystals (figures 4B-C-E-F\&G) show that the mineral is enriched in niobium, yttrium and REE elements (table 1).

The structure of fergusonite group is comparable to that of samarskite group but with large A-sites. Most of these minerals are monoclinic, although orthorhombic and tetragonal unit cells arise from cation ordering. Similar to other (Y, REE, U, Th)-(Nb, $\mathrm{Ta}, \mathrm{Ti}$ ) oxides, fergusonite (ideal formula: $\mathrm{YNbO}_{4}$ ), occurs typically as an accessory component in granitic pegmatites [3].

\subsubsection{HF-Zircon}

Zircon occurs as dark brown massive compact grains that are generally translucent to opaque. The surface of the zircon grains is generally ill defined, rough, and dull. The studied zircon crystals possesses three colored varieties; yellowish brown (figure 5A), reddish brown (figure 5C) and dark greenish (figure 5E). Environmental Scanning Electron Microscope (ESEM) data of the studied zircon crystals (figures 5 B-D \& F) show that the mineral is enriched in zirconium, silica and hafnium (table 2). Because the zircon of the investigated Abu Dob pegmatite frequently contains hafnium in amounts ranging between 6.09 and $7.51 \mathrm{wt} \%$, the studied zircon as designated as Hf-rich zircon according to the scheme of Correia Neves et al. [21]. 


\subsubsection{Kasolite}

Kasolite is generally distinguished from the other uranium silicates by its crystal habit and luster. It is a hydrated silicate of lead and hexavalent uranium and is the only uranyl silicate with lead as major cation. These grains usually occur as massive granular form composed of druses of rod like crystals. They are characterized by their waxy or greasy luster. Environmental Scanning Electron Microscope (ESEM) data of the studied kasolite crystals (figure 5G) show that the mineral is enriched in uranium, silica and lead (table 3).

\subsubsection{Titanite: $\left[\mathrm{CaTiSiO}{ }_{5}\right]-$ Allanite-Ce $\left[(\mathrm{Ca}, \mathrm{REE}, \mathrm{Th})_{2}\left(\mathrm{Fe}^{2+}, \mathrm{Al}\right)_{3} \mathrm{Si}_{3} \mathrm{O}_{12}(\mathrm{OH})\right]$ association}

Titanite occurs as brownish yellow massive translucent crystals of anhedral to subhedral form and having a characteristic vitreous luster. Generally, it is widespread as an accessory mineral occurring in igneous rocks. It is a calcium titanium silicate mineral $\left(\mathrm{CaTiSiO}_{5}\right)$ with sphenoid habit. The obtained ESEM data of the investigated titanite (figure $5 \mathrm{H}$ ) have resulted in table 3. Scanning electron microphotographs confirm that almost all the investigated titanite crystals characteristically contain several black inclusions of allanite-Ce (figure $5 \mathrm{H}$ ) and table 3.

Pure monomineralic sample from fergusonite crystals of various colors and zircon were prepared by hand picking and subjected to XRD analyses. XRD diffractogram of fergusonite-Y of Abu Dob pegmatite (figure 6A) confirms to the ASTM card index No. 9-0433. The obtained data confirms to the ASTM card index No. 081-0591 for Abu Dob zircon (figure 6B).

Table (1): SEM chemical analyses of different colors of fergusonite-Y.

\begin{tabular}{|c|c|c|c|c|c|}
\hline Element oxide & Yellow & brown & Velvet-y & $\mathbf{v}$ brown & Very deep brown \\
\hline $\mathrm{Nb}_{2} \mathrm{O}_{5}$ & 40.05 & 36.88 & 37.96 & 38.69 & 41.49 \\
\hline $\mathrm{Ta}_{2} \mathrm{O}_{5}$ & 8.18 & 4.74 & 4.67 & 3.69 & 4.10 \\
\hline $\mathrm{TiO}_{2}$ & 0.68 & 0.48 & 0.53 & 0.71 & 0.78 \\
\hline $\mathbf{U O}_{2}$ & 5.48 & 5.17 & 3.64 & 3.71 & 3.30 \\
\hline $\mathrm{ThO}_{2}$ & 8.52 & 3.65 & 6.71 & 5.92 & 4.04 \\
\hline $\mathrm{FeO}$ & 4.77 & 0.22 & 1.41 & - & - \\
\hline $\mathrm{Y}_{2} \mathrm{O}_{5}$ & 8.95 & 12.93 & 14.80 & 14.45 & 15.60 \\
\hline $\mathrm{CaO}$ & 2.19 & 0.96 & 0.66 & 0.48 & 0.80 \\
\hline $\mathrm{Ce}_{2} \mathrm{O}_{3}$ & 4.26 & - & 1.03 & 1.43 & - \\
\hline $\mathrm{Nd}_{2} \mathrm{O}_{3}$ & 2.66 & 2.38 & 2.64 & 3.22 & 3.50 \\
\hline $\mathrm{Er}_{2} \mathrm{O}_{3}$ & - & 6.03 & 4.84 & 4.77 & 5.50 \\
\hline $\mathrm{Sm}_{2} \mathrm{O}_{3}$ & - & 2.42 & 2.74 & 2.61 & 2.40 \\
\hline $\mathrm{Gd}_{2} \mathrm{O}_{3}$ & - & 3.13 & 2.24 & 2.16 & 2.41 \\
\hline $\mathrm{Dy}_{2} \mathrm{O}_{3}$ & - & 7.25 & - & 6.23 & 6.30 \\
\hline $\mathrm{Yb}_{2} \mathrm{O}_{3}$ & 4.27 & 9.56 & 9.57 & 7.16 & 8.30 \\
\hline $\mathrm{Al}_{2} \mathrm{O}_{3}$ & 0.28 & 1.94 & 3.42 & 3.20 & 1.48 \\
\hline $\mathrm{SiO}_{2}$ & 9.71 & 1.26 & 3.68 & 2.28 & - \\
\hline Total & 100 & 100 & 100 & 100 & 100 \\
\hline
\end{tabular}



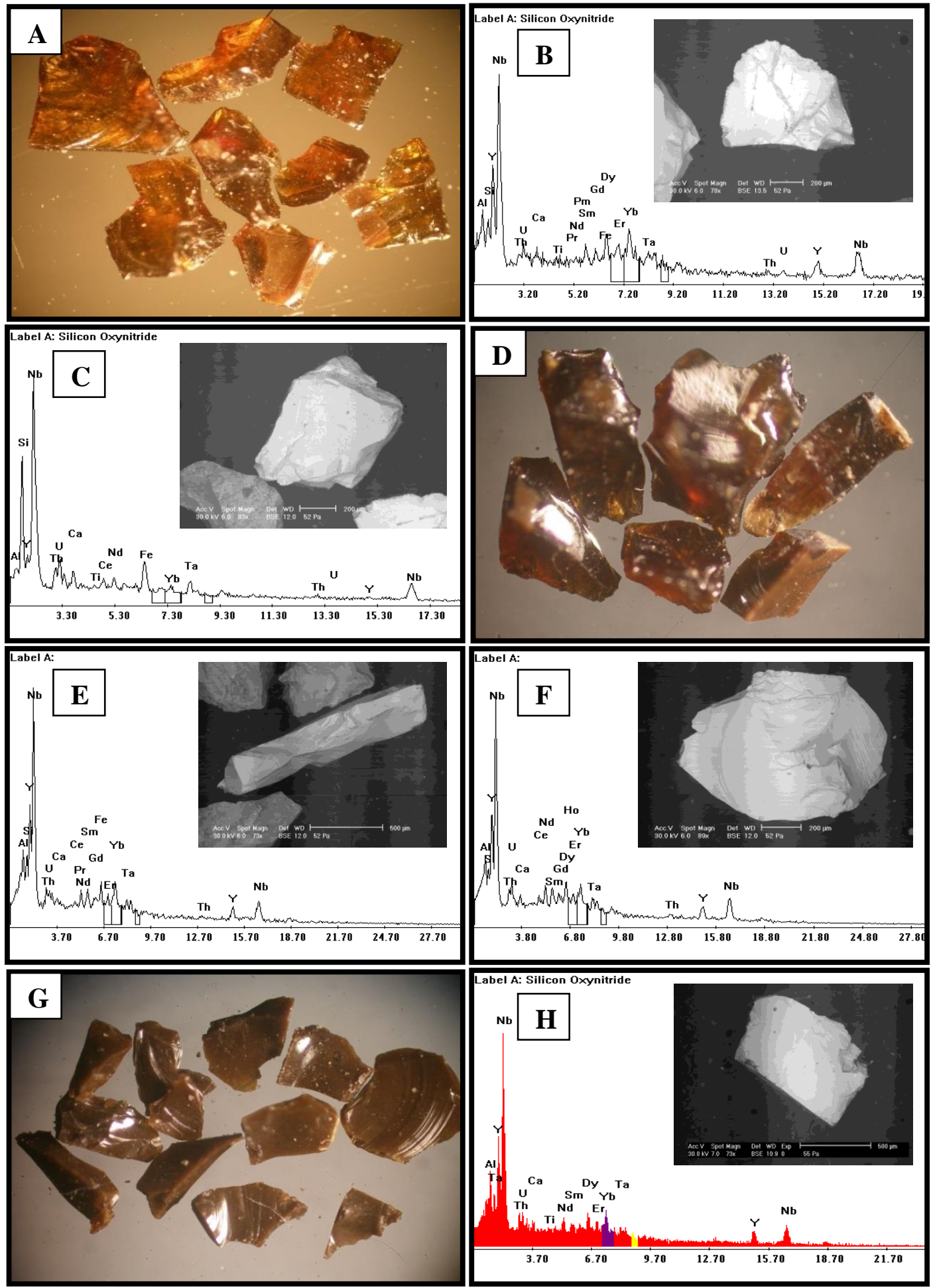

Fig. 4: (A) Fergusonite crystals with yellowish brown color, Binocular microscope; (B\&C) EDX and BSE image of yellowish brown fergusonite; (D) Fergusonite crystals with velvet-yellow brown to honey yellow in color; (E\&F) EDX and BSE image of velvet-yellow brown fergusonite crystals; (G) Fergusonite crystals of deep brown color; (H) EDX and BSE image of deep brown fergusonite. 


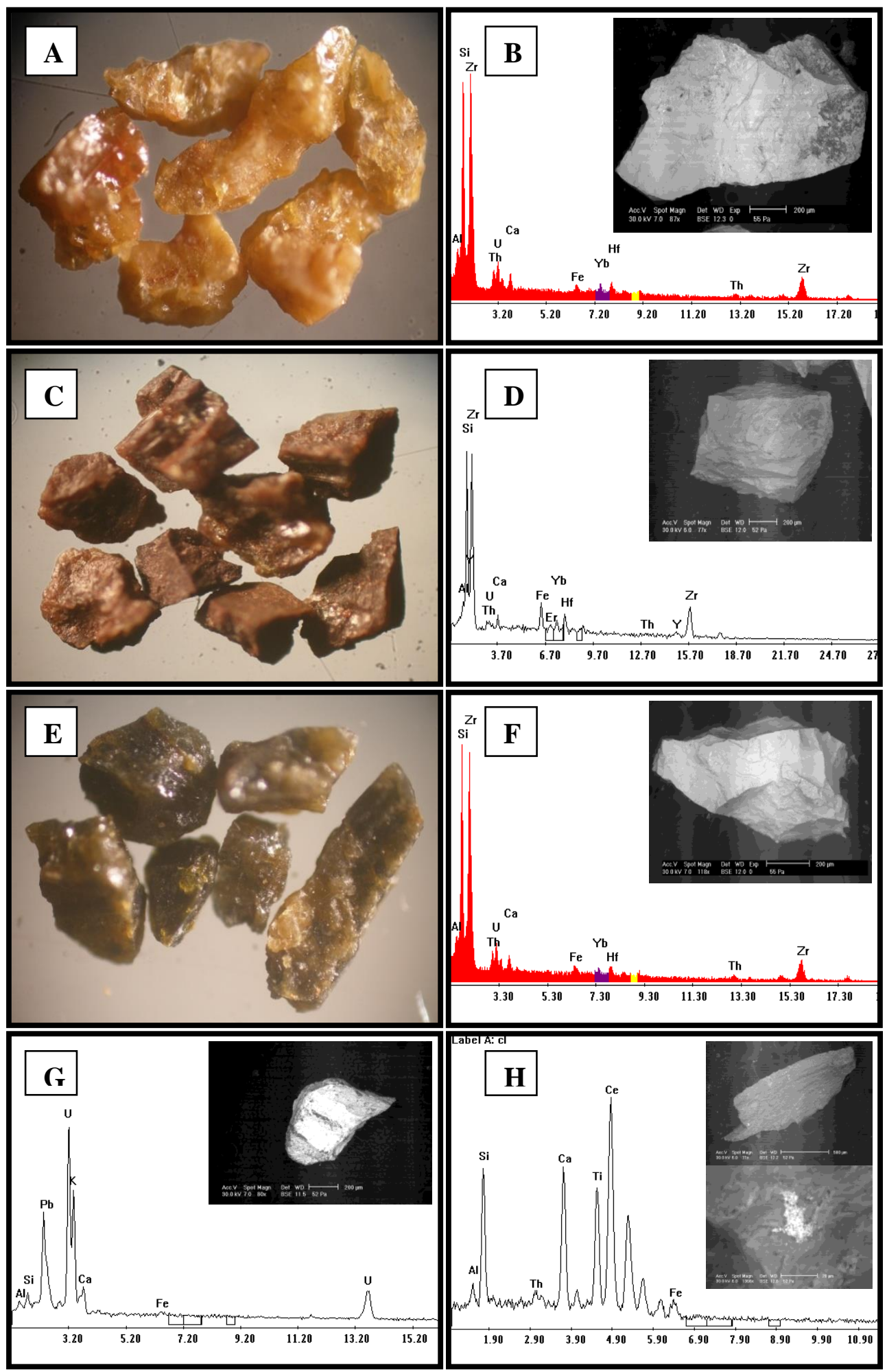

Fig. 5: (A) Zircon crystals with yellowish brown color; (B) EDX and BSE image of zircon; (C) Zircon crystals reddish brown color; (D) EDX and BSE image of zircon; (E) Zircon crystals with dark greenish color; (F) BSE image of zircon; (G) EDX and BSE image of kasolite; (H) EDX and BSE image of titanite and associated allanite-Ce. 
Table (2): SEM chemical analyses of different colors of Hf-zircon.

\begin{tabular}{|c|c|c|c|}
\hline Elements & Yellowish brown & Reddish brown & Dark greenish \\
\hline $\mathbf{Z r}$ & 47.74 & 53.13 & $\mathbf{4 6 . 9 7}$ \\
\hline $\mathbf{T h}$ & 8.10 & 7.40 & $\mathbf{8 . 5 4}$ \\
\hline $\mathbf{U}$ & 7.80 & 1.76 & $\mathbf{7 . 8 5}$ \\
\hline $\mathbf{H f}$ & 6.34 & 7.51 & $\mathbf{6 . 0 9}$ \\
\hline $\mathbf{F e}$ & 1.21 & 3.21 & $\mathbf{1 . 5 1}$ \\
\hline $\mathbf{S i}$ & 19.15 & 11.39 & $\mathbf{2 0 . 2 0}$ \\
\hline $\mathbf{C a}$ & 1.10 & 1.18 & $\mathbf{1 . 6 9}$ \\
\hline $\mathbf{A l}$ & 2.97 & 1.69 & $\mathbf{2 . 8 4}$ \\
\hline Yb & 4.93 & 4.30 & $\mathbf{4 . 3 0}$ \\
\hline $\mathbf{Y}$ & - & 6.57 & - \\
\hline Er & - & 1.87 & - \\
\hline Total & 100 & 100 & $\mathbf{1 0 0}$ \\
\hline
\end{tabular}

Counts

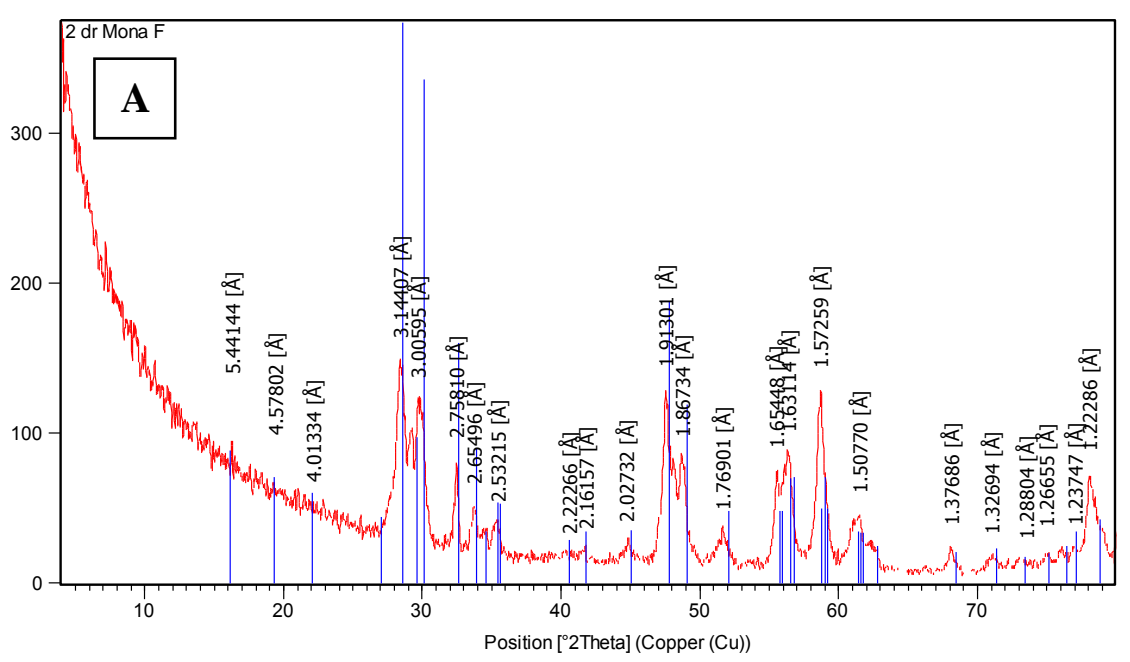

Counts

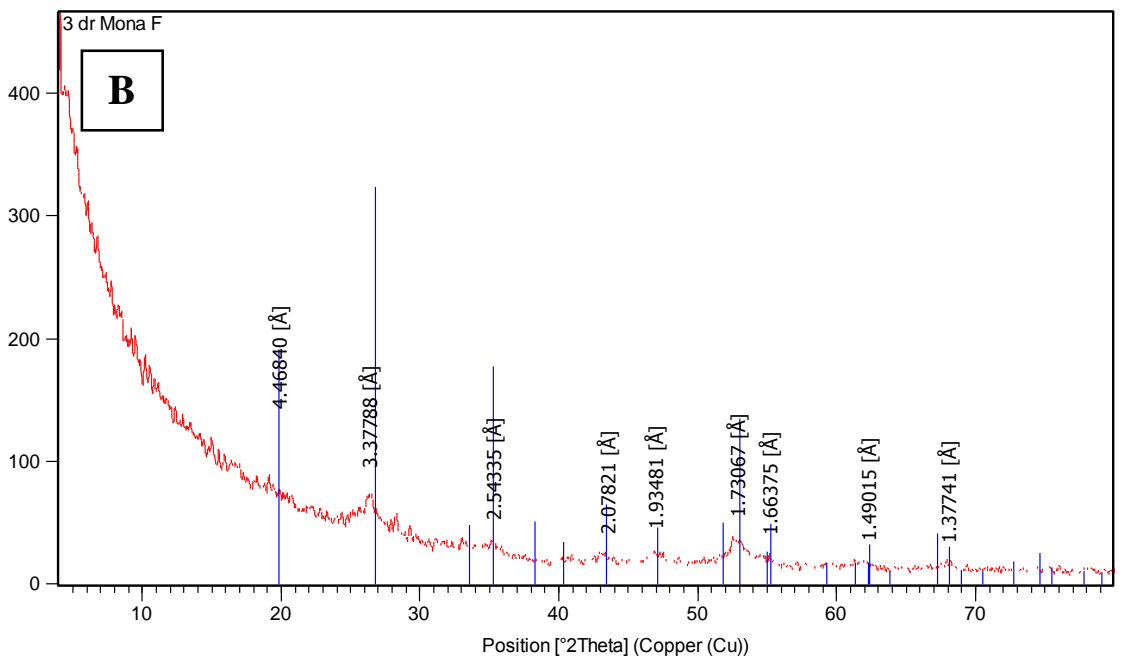

Fig. 6: (A) XRD diffractogram of fergusonite-Y; (B) XRD diffractogram of zircon. 
Table (3): SEM chemical analyses of kasolite and titanite - allanite-Ce association.

\begin{tabular}{|c|c|c|c|c|}
\hline Element oxide, Wt. (\%) & Kasolite & Titanite & \multicolumn{2}{|c|}{ Allanite-Ce } \\
\hline $\mathbf{A l}_{\mathbf{2}} \mathbf{O}_{3}$ & 1.34 & 7.14 & 3.63 & $\mathbf{4 . 1 8}$ \\
\hline $\mathbf{S i O}_{2}$ & 2.01 & 27.20 & 16.46 & $\mathbf{2 0 . 5 2}$ \\
\hline $\mathbf{C a O} \mathbf{T i O}_{2}$ & 2.64 & 30.08 & 9.71 & $\mathbf{6 . 2 2}$ \\
\hline $\mathbf{F e}_{2} \mathbf{O}_{3}$ & - & 30.54 & 11.38 & $\mathbf{8 . 2 8}$ \\
\hline $\mathrm{Ce}_{2} \mathbf{O}_{3}$ & 0.79 & 5.05 & 2.27 & $\mathbf{2 . 3 4}$ \\
\hline $\mathbf{T h O}_{2}$ & - & - & 52.95 & $\mathbf{5 2 . 1 2}$ \\
\hline $\mathbf{U O}_{2}$ & - & - & 3.60 & $\mathbf{3 . 5 7}$ \\
\hline $\mathbf{P b O}_{2}$ & 74.15 & - & - & $\mathbf{1 . 2 7}$ \\
\hline $\mathbf{K}_{2} \mathbf{O}$ & 18.22 & - & - & - \\
\hline $\mathbf{T o t a l}$ & 0.85 & - & - & - \\
\hline $\mathbf{1 0 0}$ & 100 & 100 & $\mathbf{1 0 0}$ \\
\hline
\end{tabular}

\subsection{Physical Upgrading of Fergusonite-Y and Hf-Zircon}

Preparation of a suitable feed for separation is very useful for attaining the maximum efficiency of the used equipment. The size of the separated particles is the most important factor affecting separation [22-25].

\subsubsection{Comminution and size analysis}

Table 4 shows the results of the granulometric analysis and distribution of heavy minerals among the various size fractions. The heavy minerals content of each size fractions was determined using heavy liquid separation. These results suggest that the crushing operation was successful for saving the majority of the heavy minerals content within the size fraction $(-1.00+0.063 \mathrm{~mm})$. In addition, these results reveal that about $89.70 \%$ from the original heavy minerals present in the original sample was saved within $88.04 \%$ by weight.

Table (4): Granulometric analyses and heavy mineral contents among the various size fractions of the studied pegmatite.

\begin{tabular}{|c|c|c|c|}
\hline $\begin{array}{c}\text { Size } \\
(\mathbf{~ m m})\end{array}$ & Wt (\%) & $\begin{array}{c}\text { Assay (\%) } \\
\text { H.M. }\end{array}$ & Distribution (\%) \\
\hline$-1.00+0.700$ & 26.09 & 35.20 & 31.00 \\
\hline$-0.700+0.500$ & 16.48 & 32.00 & 17.80 \\
\hline$-0.500+0.250$ & 23.07 & 27.60 & 21.50 \\
\hline$-0.250+0.125$ & 13.47 & 25.20 & 11.50 \\
\hline$-0.125+0.063$ & 8.92 & 26.40 & 7.90 \\
\hline $\begin{array}{c}\text { Deslimed } \\
-1.00+0.063\end{array}$ & 88.04 & 29.18 & 89.70 \\
\hline-0.063 mm \& \\
slimes
\end{tabular}




\subsubsection{Gravitative separation}

In order to reduce the bulk light gangue minerals from the deslimed size fractions and attain clean concentrate for each size fraction, the deslimed size fractions $(-1.00+0.700$ $\mathrm{mm}),(-0.700+0.500 \mathrm{~mm}),(-0.500+0.250 \mathrm{~mm}),(-0.250+0.125 \mathrm{~mm})$ and $(-0.125+$ $0.063 \mathrm{~mm}$ ) were separately fed to the Wilfely shaking table to obtain a primary concentration. The predetermined conditions of this operation was optimized by using a rate of feed of $5 \mathrm{~kg} / \mathrm{hr}$, water flow rate of $4 \mathrm{~L} / \mathrm{min}$, stroke length of $10 \mathrm{~mm}$ and an optimum table inclination of $8^{\circ}$. The obtained cleaner concentrates were mainly composed of fergusonite and zircon. The results of the tabling operations shown in table 5 reveal that the final concentrates of tabling operations containing $72.56 \%$ heavy minerals with a recovery of $79.58 \%$ in $32.60 \%$ by weight out of the deslimed size fraction $(-1.00+0.063 \mathrm{~mm})$ feed having $29.18 \%$ heavy minerals.

\subsubsection{Magnetic separation}

A considerable amount of pure monomineralic samples of fergusonite and zircon (about $0.5 \mathrm{gm}$ for each mineral variety) in the size range of $400-200 \mu \mathrm{m}$ were prepared and subjected to magnetic separation using the Frantz Isodynamic separator (Model LB 1) in order to determine the behavior of each mineral. The setting of the separator during this study was $\left(20^{\circ}\right)$ forward slope and $\left(5^{\circ}\right)$ side slope. The mineral grains of each mineral variety were carefully prepared by hand picking under binocular microscope and generally free from inclusions or locked fragments of other minerals. Fergusonite is separated in the range between 0.1-0.4 amperes. The best range of concentration is between 0.2-0.25 amperes (figure 7A). Zircon is separated in the range between 0.2-0.7 amperes and the best range of concentration is between 0.4-0.6 amperes (figure 7A).

The tabling concentrate of each size fraction was then subjected to the laboratory Carpco high intensity lift-type magnetic separator Model MLH (13) III-5 in order to obtain pure concentrates of each fergusonite and zircon. In this type of dry separator, the magnetic materials are lifted magnetically up against gravity in comparison to other separators that have gravity operating in the same general direction as magnetic force. This separator utilizes a vibratory feeder to transport the feed horizontally through an adjustable magnetic field zone where the magnetic force acting on the particles is perpendicular upwards.

The advantage of this principle is a production of high purity magnetic products and separation of more than one magnetic material. Separation of fergusonite was achieved as magnetic fraction at a medium air gap between the surface of the rotor and the magnetized pole of $1.5 \mathrm{~mm}$ and with a magnetic field current range of 1-1.5 amperes. The speed of the roll and the feed rate were adjusted at $50 \mathrm{rpm}$ and $150 \mathrm{~g} / \mathrm{min}$ respectively. The non-magnetic fraction is a pure concentrate of zircon (figure 6B).

Mineralogical analyses of the magnetic separation products (magnetic and nonmagnetic fractions) indicated that the final magnetic concentrate of fergusonite assays up to $98 \%$ and the final non-magnetic concentrate of zircon assays up to $96 \%$. A schematic sequence of the processes followed in the upgrading operations is presented in the form of a proposed flowsheet in figure 8. Figure 9 represent a close up view for the products obtained from gravitative and magnetic separation respectively. 
Table (5): Assay and material balance of the various products of gravitative separation.

\begin{tabular}{|c|c|c|c|c|}
\hline $\begin{array}{l}\text { Size fractions } \\
(\mathrm{mm})\end{array}$ & Product of tabling & $\begin{array}{l}\text { Wt. }(\%) \\
\text { Overall }\end{array}$ & $\begin{array}{c}\text { Assay \% } \\
\text { H.M. }\end{array}$ & $\begin{array}{c}\text { Distribution } \\
(\%)\end{array}$ \\
\hline \multirow{3}{*}{$-1.00+0.700$} & Conc. & 9.3 & 95.9 & 25.34 \\
\hline & Tail & 16.8 & 11.9 & 5.68 \\
\hline & Feed & 26.09 & 35.2 & 31 \\
\hline \multirow{3}{*}{$\begin{array}{l}-0.700 \\
+0.500\end{array}$} & Conc. & 8 & 69.7 & 17.4 \\
\hline & Tail & 8.5 & 2 & 0.53 \\
\hline & Feed & 16.48 & 32 & 17.8 \\
\hline \multirow{3}{*}{$\begin{array}{r}-0.500 \\
+0.250\end{array}$} & Conc. & 9.2 & 61.2 & 20.40 \\
\hline & Tail & 13.87 & 2.2 & 1.10 \\
\hline & Feed & 23.07 & 27.6 & 21.5 \\
\hline \multirow{3}{*}{$\begin{array}{l}-0.250 \\
+0.125\end{array}$} & Conc. & 3.2 & 86.2 & 10.97 \\
\hline & Tail & 10.27 & 1.6 & 0.65 \\
\hline & Feed & 13.47 & 25.2 & 11.5 \\
\hline \multirow{3}{*}{$-0.125+0.063$} & Conc. & 2.9 & 49.8 & 5.47 \\
\hline & Tail & 6.02 & 10.7 & 2.44 \\
\hline & Feed & 8.92 & 26.4 & 7.9 \\
\hline
\end{tabular}

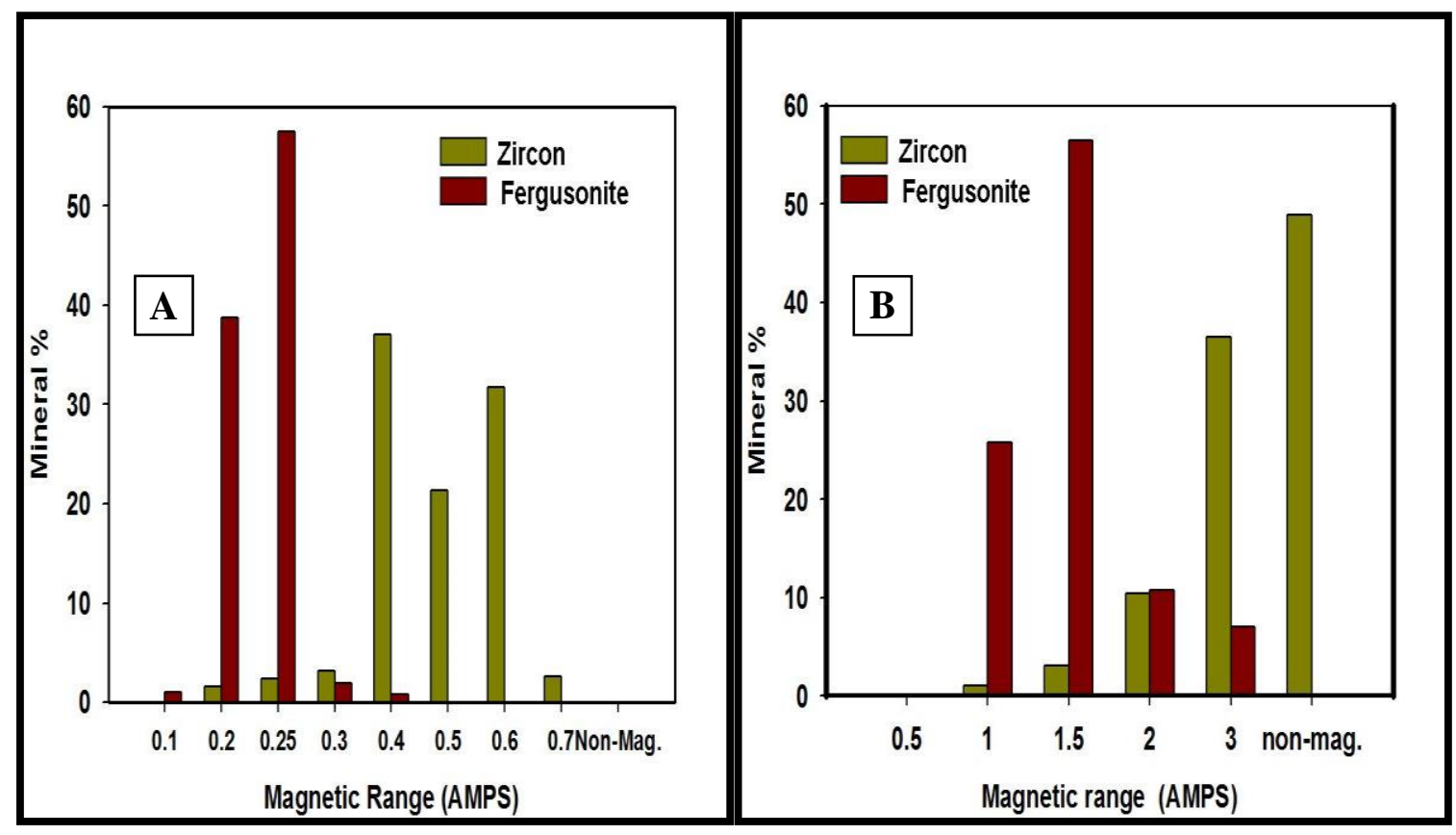

Fig. 7: Histogram show the percentage of fergusoite and zircon separated as magnetic fractions at different current intensities. (A) Frantz Isodynamic Separator; (B) Laboratory Carpco high intensity lift-type magnetic separator. 


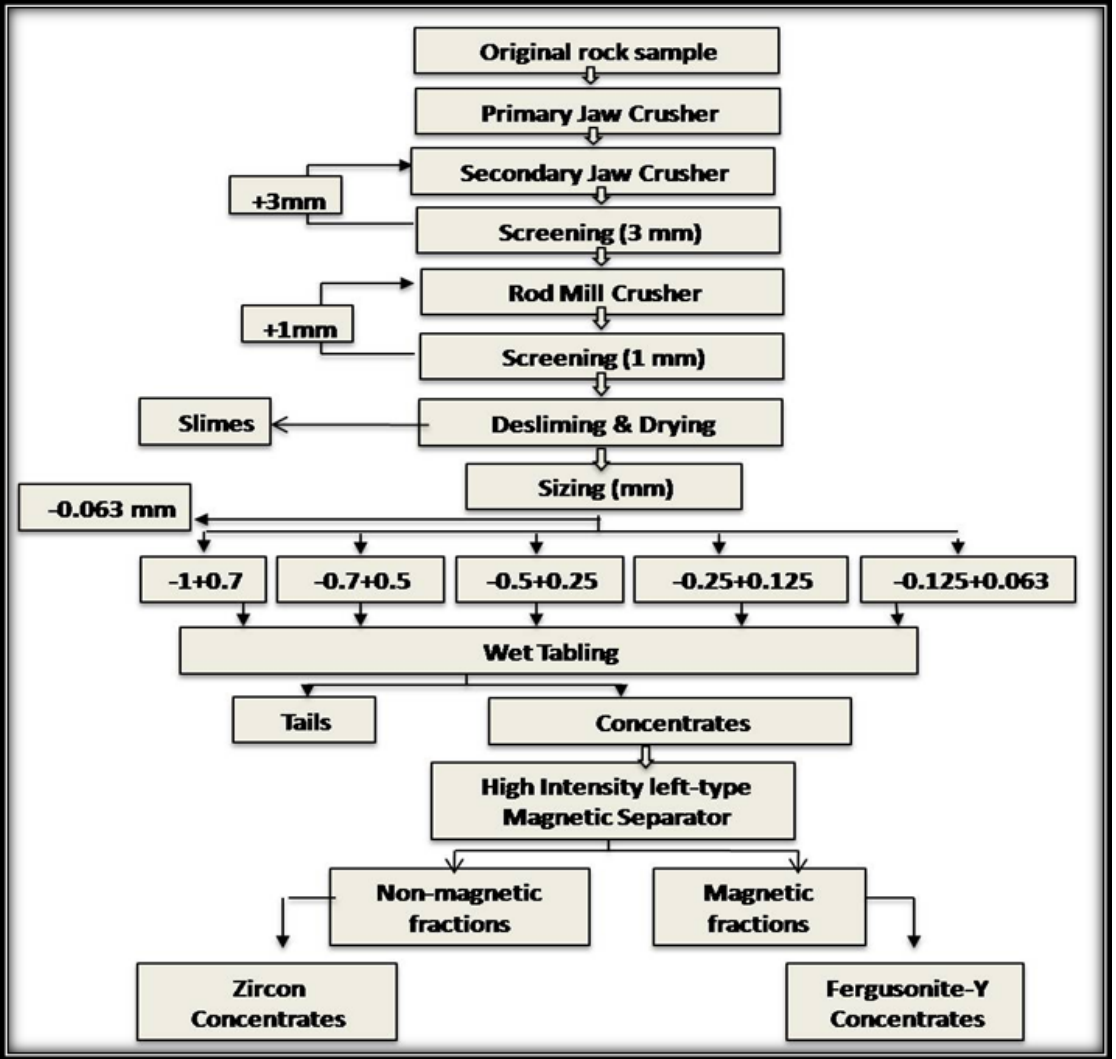

Fig. 8: Proposed flowsheet for beneficiation of fergusonite and zircon from AbuDob pegmatite.

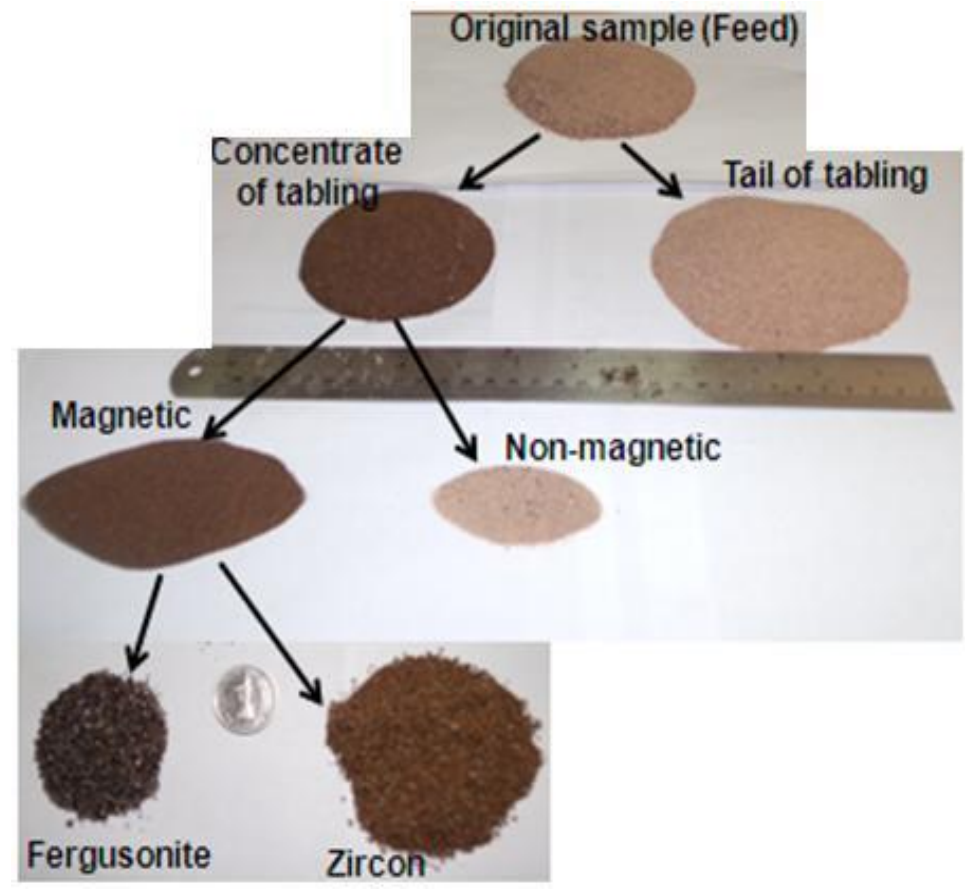

Fig. 9: Close up view for the products obtained from gravitative and magnetic separation respectively. 


\section{Conclusions}

Mineralogy of the studied radioactive pegmatite from Abu Dob area revealed that both fergusonite and zircon represent about $28 \%$ by the weight of the original rock sample. Detailed microscopic examination, X-ray diffraction (XRD) and Environmental Scanning Electron Microscope (ESEM) were used to identify and describe the studied minerals. Gravitative separation proved rather good potentialities to attain a good concentrate of both fergusonite-Y and Hf-Zircon with an acceptable recovery. By applying the laboratory Carpco high intensity lift-type magnetic separator for the tabling concentrates, it was possible to attain a good separation between fergusonite-Y as magnetic concentrate and Hf-Zircon as non-magnetic concentrate.

\section{REFERENCES}

[1] Matsubara, S.; Kato, A. and Matsuyama, F.: "Nb-Ta minerals in a lithium pegmatite from Myokenzen". Ibaraki prefecture, Japan. Mineralogical journal, 17, pp. 338-345, (1995).

[2] Hanson, S. L.; Simons, W. B.; Falster, A. U.; Foord, E. E. and Lichte, F. E.: "Proposed nomenclature for samarskite-group minerals: new data on ishikawaite and calciosamarskite". Mineralogical magazine, 63, pp. 27-63, (1999).

[3] Ercit, T. S.: "The geochemistry and crystal chemistry of columbite group granitic pegmatites, southwest Grenville Province, Canadian Shield". Canadian mineralogist, 32, pp. 421-438, (1994).

[4] William, S. B.; Hanson, S. L. and Falster, A. U.: "Samarskite-Yb: a new species of the samarskite group from the Little Pasty pegmatites, Jefferson County, Colorado, Can". Mineral. 44/5, pp. 1119-1125, doi: 10.2113/gscanmin.44.5.1119, (2006).

[5] Pal, D. C.; Mishra, B. and Bernhardt, H. J.: "Mineralogy and geochemistry of pegmatite-hosted $\mathrm{Sn}-, \mathrm{Ta}-\mathrm{Nb}$-, and $\mathrm{Zr}$ - $\mathrm{Hf}$ bearing minerals from the southeastern part of the Bastar- Malkangiri pegmatite belt, Central India". Ore geology reviews, 30, pp. 30-55, (2007).

[6] Raslan, M. F.; El-Shall, H. E.; Omar, S. A. and Daher, A. M.: "Mineralogy of polymetallic mineralized pegmatite of Ras Baroud granite, Central Eastern Desert, Egypt". Journal of mineralogical and petrological sciences, 105/3, doi: 10.2465/jmps.090201, pp. 123-134, (2010).

[7] Raslan, M. F. and Ali, M. A.: "Mineralogy and mineral chemistry of rare-metal pegmatites at Abu Rusheid granitic gneisses, South Eastern Desert, Egypt". Geologija, 54/2, pp. 205-222, (2011).

[8] Raslan, M. F.: "Occurrence of Samarskite-Y in the Mineralized Umm Lassifa Pegmatite, Central Eastern Desert, Egypt". Geologija, 58/2, pp. 213-220, (2015).

[9] Schwartz, M. O.: "Geochemical criteria for distinguishing magmatic and metasomatic albite-enrichment in granitoids: Examples from the Ta-Li granite Yichun (China) and the Sn-W deposits Tikus (Indonesia)". Mineralium deposita, 27, pp. 101-108, (1992).

[10] Abdalla, H. M.; Helba, H. A. and Mohamed, F. H.: "Chemistry of columbitetantalite minerals in rare metal granitoids, Eastern Desert, Egypt". Mineralogical magazine, 62, pp. 821-836, (1998).

[11] Cerny, P.: "Distribution, affiliation and derivation of rare-element granite pegmatites in Canadian Shield". Geologische Rundschau, 79, pp. 183-226, (1990). 
[12] Abdalla, H. M. and El Afandy, A. H.: "Contrasting mineralogical and geochemical characteristics of two A-type pegmatite fields, Eastern Desert, Egypt". Egyptian mineralogists, 20, pp. 287-328, (2003).

[13] Guyonnet, D.; Planchon, M.; Rollat, A.; Escalon, V.; Tuduri, J.; Charles, N.; Vaxelaire, S.; Dubois, D. and Fargier, H.: "Material flow analysis applied to rare earth elements in Europe". Jou. Clean. Prod., (2015).

[14] Hume, W. F.: "Geology of Egypt". Vol. II, part II: The later plutonic and inner intrusive rocks, Survey of Egypt, Cairo, (1935).

[15] Ibrahim, M. E.; Shalaby, M. H. and Ammar, S. E.: "Preliminary studies on some uranium and thorium bearing pegmatites at G. Abu Dob, Central Eastern Desert". Proceeding of Egyptian academic science, 47, pp. 173-188, (1996).

[16] Ibrahim, M. E.: "Occurrence of U and REE-bearing samarskite in the Abu Dob pegmatites, Central Eastern Desert, Egypt". Proceeding of Egyptian academic science, 49, pp. 77-89, (1999).

[17] Dawood, N. A.: "Geochemical and mineralogical studies of younger granites and uraniferous pegmatites at Gabal Abu-Dob, Central Eastern Desert, Egypt". M. Sc. Thesis, Mans. Univ., p. 139, (1999).

[18] Attawiya, M. Y.; Zalata, A. A.; Ibrahim, M. E.; Mostafa, M. E. and Dawood, N. A.: "Geology, geochemistry and mineralogy of uraniferous pegmatites at Gabal Abu Dob, central Eastern Desert, Egypt". Fifth Arab conference on the peaceful uses of atomic energy, Beirut, 2000, pp. 26-45, (2000).

[19] Ammar, F. A.: "Mineralogical and radiometric studies on the uraniferous pegmatites of Abu-Dob area". Journal of environmental research, 4, pp. 52-84, (2001).

[20] Abdeen, M. M.; Greiling, R. O.; Sadek, M. F. and Hamed, S. S.: "Magnetic fabrics and Pan-African structural evolution in Najel fault Corridor in the Eastern Desert of Egypt". Journal of African earth science, pp. 93-108, (2014).

[21] Neves, J. M. C.; Numes, J. E. and Sahama, T. G.: "High hafnium members of the zircon-hafnon series from the granite pegmatites of Zambezia, Mozambique". Contrib. mineral. petrol., 67, pp. 73-80, (1974).

[22] Taggart, A. F.: "Handbook of mineral dressing and industrial minerals". John Wiley and Sons, Inc. New York, London, Sydney, (1944).

[23] Jones, M. P.: "Mineral dressing tests on the extraction of columbite and other heavy minerals from the Olegi younger granite". Rec. Geol. Surv., Nigeria 1959 (published in 1960), (1960).

[24] Pryor, E. J.: "Mineral processing". Applied science publishers limited, $3^{\text {rd }}$. edition, London, (1974).

[25] Gaudin, A. M.: "Principles of mineral dressing". TATA McGraw Hill publishing Co. Ltd., New Delhi, (1980). 